\title{
Vissza a természetbe! \\ - A fenntarthatóságra nevelés aktuális kérdései az oktatásban
}

\author{
Kolosai Nedda \\ Eötvös Loránd Tudományegyetem Tanitó- és Óvóképző Kar Neveléstudományi Tanszék
}

A fenntartható fejlődés olyan fejlődést jelent, amely kielégíti a jelen szükségleteit, anélkül, hogy veszélyeztetné a jövő nemzedékek esélyét arra, hogy ők is kielégítsék szükségleteiket (WCED, 1987, Kaga, 2008). A fenntarthatóságra nevelés ott kezdődik, hogy megtanulunk újra kapcsolódni a természethez, egymáshoz, önmagunkhoz. A környezeti nevelés vagy fenntarthatóságra nevelés célja azoknak az emberi képességeknek és magatartásformáknak pozitív formálása, amelyek egy ökológiailag, szociálisan, gazdaságilag és politikailag fenntartható társadalom létrejöttéhez szükségesek. Azaz olyan össztársadalmi folyamat, melyben a felsőoktatás és a közoktatás csupán egyegy részterületet képvisel. Ezek a részterületek azonban alapvető fontosságúak azon az úton, amelyen egyre szélesebb körben nyer polgárjogot az élhető természeti és társadalmi környezet megóvásának közös felelőssége, hiszen a felsőoktatás és a közoktatás közvetítheti a közös felelősség megtapasztalását a felnövekvő nemzedékek számára (Havas \& Varga, 2006).

Hogyan lehet a pedagógiai folyamatban a gyerekek számára megjeleníteni, egyben vizsgálhatóvá tenni az ember és környezete között lévö bonyolult kapcsolatrendszert? 


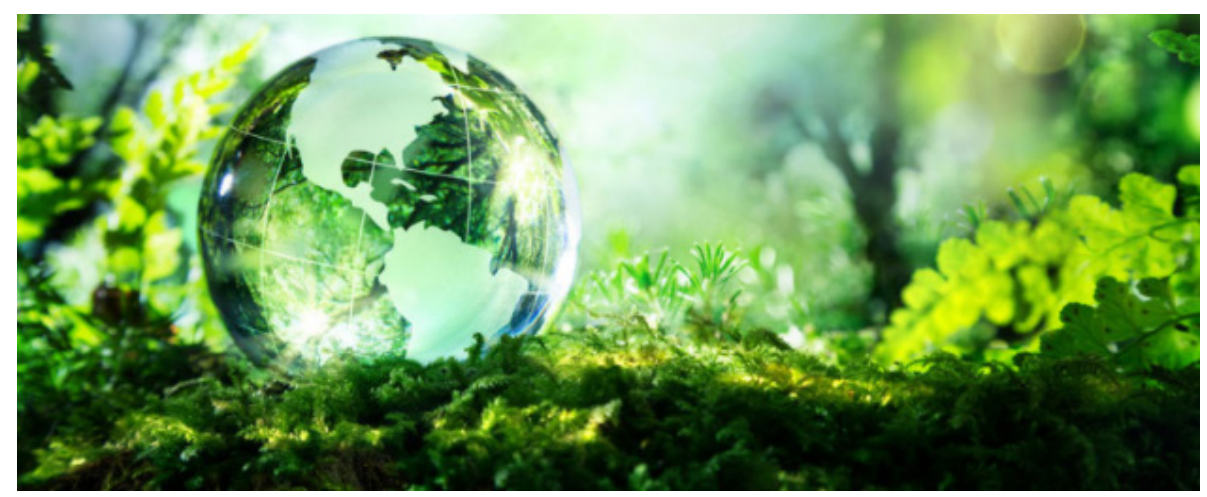

Kép forrása: shutterstock ${ }^{l}$

A Gyermeknevelés Tudományos Folyóirat tematikus írásai több oldalról járják körül ezt a fontos kérdést és témát, melynek három évtizedre visszanyúló magyar nyelvű irodalma van. Magyarországon a környezeti nevelésben az egyik akadályt az jelenti, hogy a fenntarthatóság pedagógiájának tudományközi és összetett tartalmai nehezen illeszthetőek a tantárgyközpontú tantervekbe, illetve az oktatási folyamatba. További akadályt jelent, hogy a pedagógusok sokszor maguk sem kellően tájékozottak a kérdéskörben, mert az alapképzésnek, valamint a továbbképzéseknek nem kötelező eleme a felkészítés a fenntarthatóság területeire és tartalmaira. Érdekes hazai empirikus kutatási adatok bizonyítják, hogy azokban az iskolákban és óvodákban a legeredményesebb a környezeti nevelés, amelyekben ez a pedagógiai terület a pedagógiai program gerincét alkotva egyaránt elősegíti a szervezetfejlesztést, az erőforrás-gazdálkodást, a partnerségek működtetését, valamint a tanuló szervezetté válást (Havas \& Varga, 2006).

\section{A fenntarthatóságra nevelés magyarországi és nemzetközi előzményei az oktatásban}

A nyolcvanas években több OECD országban megerősödtek azok a civilszervezetek és csoportok, amelyek kifejezték, hogy a gazdaság intenzív fejlödése eredményezi mind a kiterjedt környezetszennyezést, mind a természet pusztulását. Ezzel egyidejűleg ugyanezen országoknak kényszerủen szembe kellett nézniük azzal a kihívással, amit a gyors gazdasági- és társadalmi változások állítottak a köz-, és a felsőoktatás elé. A szembenézés eredményeképpen sok ország felülvizsgálta bürokratikus és központi irányítású oktatáspolitikáját, azután nagyobb önállóságot adott, több felelősséget hárított

$\overline{{ }^{1} \text { https://www.shutterstock.com/hu/image-photo/crystal-globe-resting-on-moss-forest-274566236 }}$ 
az iskolákra, a helyi közösségekre a fenntarthatósággal kapcsolatos tanulásfejlesztési innovációk terén (Havas \& Varga, 2006).

$\mathrm{Az} \mathrm{OECD}^{2}$ ennek a gondolkodásnak a hatására létrehozta az úgynevezett ENSI ${ }^{3}$ projektet 1986-ban, melynek alapja, lényege volt a környezeti nevelés intézményi kezdeményezéseinek támogatása. Az ENSI által képviselt oktatási innovációk keretében olyan helyi környezeti problémák kerültek a gyermekek tanulásának tartalmai közé, amelyek hatékony tanulási folyamat által, közvetlenül formálták a diákok környezettudatosságát, fenntarthatósággal kapcsolatos értékrendjét. Ezek az innovációk felkeltették a gyerekek tudományokon átívelő érdeklődését, az oktatásban a hagyományos befogadó tanulóképet felváltotta az aktív és adaptív, dinamikus tanulási modell (M. Nádasi, 2012; Wells \& Lekies, 2006).

\section{Pedagógusok akciókutatási gyakorlata a fenntarthatóságra nevelésért}

Mindezen folyamatokat különböző társadalomtudományi, elsősorban alkalmazott neveléstudományi kutatásokkal alapozták meg. Hatékonyan, gyorsan elterjedt a pedagógusok akciókutatásának alkalmazása olyan kutatási és fejlesztési módszerként, amellyel az óvodapedagógusok, a tanítók, a tanárok, általában a pedagógusok az oktatási rendszerben bekövetkező változások tevékeny részeseivé tehetők. Az akciókutatás megoldást kínált a nagyobb szabadságot nyújtó tantervkészítés következtében felmerülő problémákra is (Havas \& Varga, 2006; Kaga, 2008).

Vajon megbízhatók-e a pedagógusok abban a tekintetben, hogy mozgásterüket a tananyag megválasztásában oktatási-nevelési szempontból értékes kezdeményezések bevezetésére használják fel?

\footnotetext{
${ }^{2}$ Organization for Economic Cooperation and Development - Gazdasági Együttműködési és Fejlesztési Szervezet. Közvetlenül az OECD CERI (Center for Educational Research and Innovation - Pedagógiai Kutatási és Innovációs Központ) hozta létre a programot.

${ }^{3}$ Environmental and School Initiatives (ENSI), azaz a Környezeti Nevelési Iskolai Kezdeményezések hálózata. Az ENSI területei az iskolai környezeti nevelési kezdeményezések és az intézményi szintű innovációk.
} 


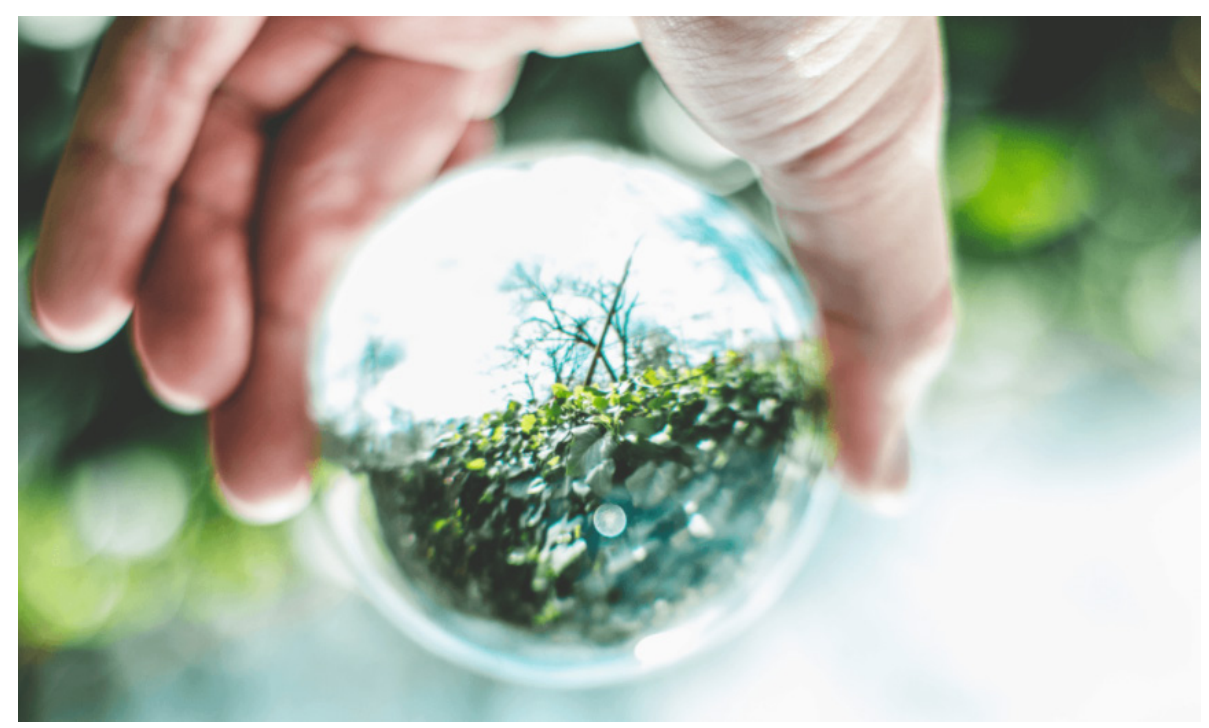

Kép forrása: Pexels.com.

A kisgyermeknevelők, óvodapedagógusok, tanítók, tanárok bevonása a kutatásba azt jelenti, hogy a pedagógusok más vonatkoztatási keretből, szakmai szempontok szerint szemlélhetik pedagógiai gyakorlatukat és tevékenységeiket. Reflektív módon azonosíthatják az átalakításra váró területeket, majd értékelhetik a változások bevezetéséhez megtett pedagógiai lépéseik eredményességét. Ezeknek az akciókutatásoknak eredményeképpen lehetővé vált a környezeti nevelés tartalmaihoz, módszereihez tartozó általános pedagógiai célok-és elvek meghatározása, a fent említett helyi, intézményi (iskolai, óvodai) felelősségvállalás mellett.

\section{Az ökológiailag fenntartható társadalom melletti elkötelezettség}

Ez a kutatási és oktatásfejlesztési stratégia az oktatási rendszer számos korábbi hagyományával kerülhet látványosan konfliktusba. Hiszen olyan határvonalakat lép(ett) át, amelyek ott húzódnak jelenleg is a közoktatás és a felsőoktatás, mint a tudásgyarapítás tradicionális helyszínei és -szereplői között. A fenntarthatóságra nevelési stratégia a különböző tantárgyak zárt rendjét fellazította, a gyermekek függőségi és a felnőttek felelősségi viszonyait átalakította a mindennapi pedagógiai gyakorlatban és az oktatásért felelős szervezetekben. Tulajdonképpen ez a szemléletmód a hagyományosnak tekintett európai oktatási rendszerek megújításaként, reformjaként is értelmezhetö, mivel a fent említett határvonalakra épülő közoktatási és felsőoktatási struktúrában és funkciókban széles körű változásokat képvisel. 
Azaz az ökológiailag fenntartható társadalom melletti elkötelezettség nem egyszerüen a fenntartható fejlődés tananyagba építéséről szól, hanem egy átalakulásról, szemléletváltásról, melynek során (például) az iskola mint szervezet számos területen kezdeményező és aktív módon kölcsönhatásba lép a helyi társadalmi környezettel, egyben hatást fejt ki rá.

Jelenlegi lapszámunk többféle választ ad arra a kérdésre, vajon hol tart a közoktatás és a felsőoktatás ezekben a kérdéskörökben, milyen jó gyakorlatokat és kutatásokat tudunk felmutatni a fenntarthatóságra nevelés témakörében.

\section{A 2020/3. szám írásai}

Balogh Borbála és Barnkopfné Zsoffay Klára egy dán erdőóvoda gyakorlatát mutatja meg. A tanulmány megírására az a megfigyelés késztetett a Szerzőket, hogy jelenleg mind a felnőttek, mind a gyerekek egyre jobban eltávolodnak a természeti környezettől. Mivel az egymást követő generációk mindinkább mesterséges, szabályozott, sokszor virtuális világban élnek, a természeti környezetet idegennek, fenyegetőnek élik meg, amennyiben mégis ott kell tartózkodniuk, elesettek, életképtelenek. Ezt a jelenséget felismerve, egyre több szakember a pedagógiában, a kisgyermekek nevelésében látja a megoldást.

A dán erdőóvoda modell a rendszeres szabad környezetben való tartózkodáson keresztül nyújtja a megfelelő élményeket és ismereteket a gyermekek számára környezetükről, valamint önmaguk képességeiről, ezáltal hosszútávon teremti meg annak a lehetőségét, hogy felnövekedve környezettudatos, önálló, rátermett emberekké váljanak. Az erdőóvodában a természetben való szabad játék teszi ki az óvodások napjainak csaknem egészét. A pedagógusok képzésük során maguk is megtanulnak szembenézni mentális és fizikai kihívásokkal, közben megismerik saját erősségeiket és korlátaikat (Balogh \& Barnkopfné Zsoffay, 2020).

A dán modell sok tekintetben idegennek, egyben megvalósíthatatlannak tűnik a magyar viszonyok között, érdekes átgondolnunk a magyar pedagógusok által felsorolt okait a megvalósíthatatlanságnak. Az írás felhívja a figyelmünket arra, hogy a gyermekek természetbe való visszavezetésének megvalósításában tágabbak a lehetőségeink annál, mint azt a hagyományos megoldásaink alapján hisszük. Léteznek, a közoktatásban és a felsőoktatásban kipróbált, akár radikálisnak tűnő jógyakorlatok arra, hogy új pedagógiai módszereket próbáljunk ki (Balogh \& Barnkopfné Zsoffay, 2020).

Vajon a felnőttek ki mernek-e menni a természetbe? Kulman Katalin (2020) kutatásában többek között ezt a kérdést vizsgálja. A környezeti neveléshez tartozik az egyéni felelősség érzésének kialakítása és a rendszerszemlélet elsajátíttatása - például, hogy bizonyos gazdasági, társadalmi és környezeti jelenségek egymással összefüggést mutatnak. Kulman Katalin kutatásában tanító szakos hallgatók véleményét mérte fel arról, Magyarországon milyen gazdasági tevékenységek okozzák a legtöbb környezeti problémát. A kutatás eredményei azt mutatják, nem mindegy, milyen információforrásból érkeznek 
a környezettel kapcsolatos hírek a tanítójelöltek számára. Ezt figyelembe véve, a tanítóképzés során, azokon a kurzusokon, amelyek környezeti kérdésekkel és tantárgypedagógiai elemekkel egyaránt foglalkoznak, célszerű (lenne) a hallgatókat arra ösztönözni, hogy a kérdést illetően több helyről szerezzenek információkat. Így átfogóbb képet kaphatnak a környezeti probléma kialakulásáról, az okozott károkról, a megoldási lehetőségekről és a hasonló esetek megelőzéséről. További kutatás tárgya lehet annak vizsgálata, mely források mennyire megbízható információt nyújtanak a kérdéskörben.

A kutatás szerint a megkérdezett tanító szakos hallgatók inkább valamilyen nemzetgazdasági ágnak tulajdonítják a levegőszennyezést és nem a háztartásoknak, miközben statisztikai adatok alapján a háztartások által kerül a legtöbb káros hatású gáz a légkörbe. Kulman Katalin írása rávilágít a pedagógusképzés felelősségére. Ahhoz, hogy a tanító kilépjen az iskola, a tanterem falain kívülre és megismertesse a tanítványaival a környezetet, szüksége van belső indíttatásra, értékrendre, emellett birtokában kell lennie a megfelelő ismereteknek (Kulman, 2020).

A gyerekek számára a tevékenységközpontú módszerek alkalmazása segítséget nyújthat abban, hogy az ember tevékenységeinek környezetkárosító hatását felfedezzék, az ok-okozati összefüggéseket meglássák és megértsék (Csenger, 2015). Bauer Zita és Gonda Judit írásukban amellett érvelnek, hogy a gyermeki tevékenységek a környezet megismerése mellett segítik az ökológiai- és rendszerszemlélet, valamint a környezet iránti pozitív attitüdök kialakulását, melyek a fenntarthatóság pedagógiai tartalmának megvalósulásában fontos alappilléreket jelentenek. Ezen célok elérésének alapvető eszközei lehetnek a tanórán kívüli foglalkozások, így a szakkörök is. A Szerzők által vezetett szakkör kialakításában alapvető szempont volt, hogy a gyerekek aktív résztvevőként és ne passzív szemlélőként, megfigyelőként vagy segítőként vegyenek részt a szakkör tevékenységeiben. Tapasztalatikat összegezve nyilvánvaló, hogy a negyedik osztályos gyerekeknek természetessé vált az eszközhasználat, melyet sokszor, ha volt rá lehetőség, otthon is alkalmaztak, egy-egy kísérletet újra alkottak. Érdemes az írásból felfejteni, mi okozhatta, hogy a gyerekek lelkesedése a szakkör iránt mindvégig töretlen maradt (Bauer \& Gonda, 2020).

Nagy Bence, Persa Mária és Munkácsy Béla (2020) gyakorló pedagógusokat monitorozó kutatásukban azt az eredményt kapták, hogy az iskolán kívüli pedagógiai lehetőségeket csak a válaszadók 32,5\%-a alkalmazta eddigi oktatói munkája során. A legtöbb esetben ezek terepgyakorlat jellegű programok, tematikus táborok, szemétszedések, illetve gyárlátogatások voltak. Azok a tanárok, akik nem alkalmaznak ilyen módszereket, elsősorban idő- és erőforráshiányra hivatkoznak, illetve többek szerint ez a jellegű programszervezés nem tartozik a feladataik közé. Ugyanakkor szakirodalmi források rámutattak arra, hogy az iskolán kívüli programok segítik a diákok elméleti ismereteinek gyakorlatban történő alkalmazását, általuk olyan kulcsélményeket szerezhetnek, melyek nagyban hozzájárulnak fenntarthatósággal kapcsolatos szemléletük megfelelő formálásához. 
A fenntarthatósági nevelés nem lehet egyetlen tantárgyhoz kötött, inkább tantárgyakon átnyúló, a környezeti problémákat felismertető, együttmüködést, részvételt kívánó tanítási és tanulási tevékenység (Csenger, 2015. p. 182). Nagy Bence és munkatársai kiemelik, hogy a 2020. januárjában a Magyar Közlönyben megjelent, és 2020 szeptemberében bevezetett módosított Nemzeti Alaptantervben már nem szerepel kulcskompetenciaként a természettudományos- és technikai kompetencia. A Szerzők abban bíznak, a szabályozási környezet változása ellenére, a pedagógusok továbbra is fontosnak tartják és megvalósítják a természettudományos szemléletformálást (Nagy et al., 2020).

Darvay Sarolta Hill Katalin, Fülöp Veronika és Venyingi Beáta (2020) tanulmányukban felhívják a figyelmet a kisgyermeknevelők felelősségére, abban, hogy a fenntarthatóságra nevelést a mindennapi gyakorlatuk részévé tegyék. A fenntarthatóság környezeti-ökológiai-természeti dimenziója a kisgyermekkori nevelés színterén a környezet és a természeti rendszerek müködésének megismerését, megbecsülését, tiszteletét, azaz a környezeti nevelést jelenti. A születéstől hatéves korig terjedő évek fontosságát elismerték a gyermek fejlődésének kritikus tanulási időszakaként (Tilbury et al., 2005). A fenntarthatóságra nevelés lehetővé teszi a nevelők és a gyermekek számára, hogy előmozdítsák a felelősségvállalás alakulását, tiszteletben tartsák a természeti környezetet, aktív résztvevői legyenek a mindennapi élet adta lehetőségeknek. Mivel ebben a folyamatban az intézmény minden alkalmazottjának mintaadó szerepe van, biztosítani kell a rendszeres továbbképzések lehetőségét minden érdeklődő számára. (Darvay et al., 2020)

Timár Gábor azt a kérdést veti fel izgalmas írásában, vajon kevesebbet tudnake a jelenleg egyetemi oktatásba belépő diákok, mint néhány generációval korábban végzett társaik? Timár Gábor tapasztalata szerint, a jelenleg (a természettudományi képzésben) egyetemi tanulmányaikat végző hallgatók tárgyi tudása -az 1970-es, 1980-as években, az akkori köz- és felsőoktatásban, annak inkább az elitszegmensében szocializálódott oktatóik szempontrendszere szerint- valóban sokkal kisebb, ugyanakkor tudásuk teljesen más rétegzettségü, igen sok tekintetben kiterjedtebb képességhalmazzal párosul. Timár Gábor azt is felveti, hogy a felsőoktatás az egyetlen olyan képzési szint, ahol az oktatói kinevezéshez nem szükséges pedagógiai képzettség, véleménye szerint, az egyetemi képzés „szűz terepet” jelent a módszertani- és szakmódszertani fejlesztéseknek, amelyek valódi szakmai támogatást nyújthatnak az oktatóknak és a kutatóknak (Timár, 2020).

Wendy Russel angol nyelvü tanulmánya (Exploring the Dilemma of Planning for Play in Schools) hiánypótló a témában, a Szerző arról gondolkodik szisztematikusan, milyen arányban és milyen szakmódszertannal jelenjen meg az iskola alsó tagozatán a tervezett-, kezdeményezett, illetve a szabad játék (Russel, 2020). Az iskolai szabad játék fontosságáról jelenleg kevés szakirodalmi forrás található, így több szempontból is jelentős élmény elolvasni Wendy Russel tanulmányát.

Bagota Mónika, Szitányi Judit és Csíkos Csaba az ELTE Tanító- és Óvóképző Kar Matematika Tanszékének munkatársai egy empirikus kutatás érdekes állomását mutatják meg tanulmányukban: egyetemi oktatásba belépő pedagógus 
hallgatók matematikai képességeiről. Az írás kiváló tartalmain túl azért is jelentős, mert először járta végig az angol nyelvi lektorálás folyamatát és algoritmusát a Gyermeknevelés Tudományos Folyóirat történetében (Bagota et al., 2020).

Klein Ágnes és Márkus Éva írása arra keres szakmai válaszokat, vajon milyen a választék, ha a gyerekkönyv nem egy standard nyelvváltozatban készült, hanem nyelvjárásban íródott. Egyáltalán milyen, a gyerekek számára megfelelő, érdeklődésüket felkeltő könyvek, képeskönyvek állnak a szülők, nevelők rendelkezésére, ha a magyarországi németek egyik nyelvjárását szeretnék közelebb hozni gyermekükhöz? Milyen verbális, és milyen esztétikai jellemzők határozzák meg a jó gyerekkönyveket ebben a témában? A Szerzők konkrét példákat is javasolnak írásukban, ezzel is segítve a mindennapi pedagógiai gyakorlatot (Klein \& Márkus, 2020).

Hill Katalin könvv-ismertetése azonnal Fekete István könyveit juttatja az éles szemű, vájt fülű Olvasók eszébe. Fekete István regényeinek többségében a fó motívum maga a természet, az író minden sorából érezhető, ahogyan teljes lényét áthatja a természettel való egység, a természet iránt érzett őszinte, fellobbanó szerelem, mivel a természet iránti nyitottság az emberlét lényegét képezi. Jelenleg éppen kialakulóban van a pszichológia új irányzata, az ökopszichológia, melynek fó célja, segítséget nyújtani az embereknek vissza-, azaz hazatalálni a természethez (Hill, 2020). A Szerző Herbert Renz-Polster és Gerald Hüther 2017-ben kiadott, Vissza a gyökerekhez - Így fejlődnek „ezek a mai gyerekek” címü könyvét mutatja be, amely az Ursus Libris kiadó gondozásában jelent meg, 240 oldal terjedelemben.

A könyv állítása szerint, a természet és a gyermek viszonyuk megváltozása ellenére is ösztönös kapcsolatban maradnak. Ez a zsigeri kapcsolódás a gyermek minden sejtjében írva van, legfeljebb elhalkult, a hangosabb ingerek elnyomják a hangját. Ugyanakkor a természethez való kötődés formálódik, amikor a gyermek kapcsolatba kerül az élő és élettelen természeti elemekkel, például fákkal, madarakkal, kövekkel, illatokkal, hőmérséklettel. A kötődés élményeként úgy érzi, hozzá tartozik a fához, a fa pedig őhozzá. Itt visszakanyarodtunk az Előszó elején bemutatott dán erdőóvodához, mert a könyv Szerzői kifelteszik a kérdést: Vajon mire van szüksége a gyerekeknek? Kontrollált pedagógiai irányításra, vagy szabad felfedezésre és játékra a természetben?

A könyvben feltett kérdések valószínűleg sok pedagógusban motoszkálnak. Tény, hogy manapság a gyermekek idejük igen nagy részét töltik vezetett, szervezett pedagógiai környezetben, így kevés idejük marad az önszerveződő szabad játékra, az ebből fakadó tanulásra. A szerzőpáros gondolatébresztő felvetései segítenek megérteni a gyermekek mozgatórugóit, támogatnak abban, hogy pedagógusként könnyebben megtaláljuk az egyensúlyt a didaktikus pedagógia vezetés és a szabad, kötetlen önszervező tanulás, a spontán alakuló képességfejlődés között. Mivel mindkettő nagyon fontos és szükséges, a feladat szép kihívás. Bármelyik irány mellett köteleződünk el, a célunk mindig ugyanaz: a gyermekek támogatása, abban, hogy saját élményeikre alapozva megismerhessék, megszerethessék a természetet, így a természetért aktívan küzdő felnőttekké váljanak (Hill, 2020). 


\section{Kora gyermekkori nevelés és a fenntarthatóság komplex értelmezése}

A környezeti problémák folyamatosan változnak, ezért a kisgyermeknevelö-, az óvodapedagógus-, a tanító-, valamint a tanárképzés során elsajátított alaptudást szükséges folyamatosan fejleszteni, ennek a tudásnak a bővítését, színesítését tűzte célul lapszámunk. Kutatások megerősítik a korai évek fontosságát a gyermekek hosszú távú pozitív befolyásolásában, a gyermekek értékorientációjának kialakulásában. A kora gyermekkori nevelők óriási potenciállal rendelkeznek az értékek, attitűdök, készségek és a magatartás formálásában, amelyek támogatják a fenntarthatósági célok megvalósítását: mint például az interkulturalitás, a méltányosság, a nemek közötti egyenlőség, a demokrácia és a természeti erőforrások felhasználása (Wells \& Lekies, 2006). Egyes kutatók - például Hamilton (2015) - már egyenesen új földtörténeti korszaknak, antropocénnek nevezik korunkat, melyben az ember kezdi teljesen és egyúttal visszafordíthatatlanul átformálni a földi ökoszisztémát.

A fenntarthatóság érdekében végzett munka egy regeneráló folyamatot jelent a Föld rendszerei számára, amiben mindenkinek feladata van. A Brundtland-jelentés (WCED, 1987) óta a fenntarthatóság fogalma fokozatosan elmozdult egy komplexebb, globális értelmezés irányába. Az UNESCO (2010) fenntarthatósági koncepciója már ezt a komplexitást szemlélteti, amely a fenntarthatóság sokféle módon egymásba kapcsolódó dimenzióját egyszerre jelenít meg: a környezeti (ökológiai, természeti), a társadalmi, a gazdasági és a politikai dimenziót.

A kora gyermekkori nevelés és gondozás (Early Childhood Education and Care, ECEC) alapelveinek négy fő szempontja: a társadalom, a gyermekek, a szülők és a pedagógusok szempontja. A gyerekek, a társadalom, a szülők és a pedagógusok szempontjából egyaránt fontos az élethosszig tartó tanulásra, az önálló élmény-, és ismeretszerzésre való felkészítés (Radnóti, 2005). Ebből a nézőpontból is indokolt, hogy a pedagógusok az információszerzés lehetőségeit adekvát módon legyenek képesek megmutatni a gyerekek számára.

A fenntartható fejlődés nemcsak a környezettel és a társadalommal kapcsolatos viselkedésminták megváltoztatását igényli, hanem az emberi viselkedést formáló szélesebb rendszerek megváltoztatását. Szükséges megváltoztatni a jóléti paradigmákat, az anyagi javak felhalmozódásától a tudatosság felé elmozdulni Az oktatásnak nagy szerepe van ebben a társadalmi változásban: az egyetemi oktatók, a kora gyermekkori nevelők tudatosan, valamint saját életpéldájukon keresztül egyaránt folyamatosan adják át tudásukat, értékeiket, attitűdjeiket (Salonen et al., 2013).

Jól tudjuk, a magyar társadalom akkor lesz képes sikeres válaszokat adni a 21. század globális kihívásaira, amennyiben széles körben polgárjogot nyer a fenntarthatóság szemlélete, az élhető természeti és társadalmi környezet megóvásának közös felelőssége. A fenntarthatóságot célként kitűző komplex nevelési munkában kiemelt szerepet játszik az oktatás, amelynek - többek között - közvetítenie kell ezt a közös felelősséget a felnövekvő nemzedékek számára. A Gyermeknevelés Tudományos Folyóirat 2020/ 3. száma a fenn- 
tarthatóság eléréshez nélkülözhetetlen természeti és társadalmi környezetvédelem szemléleti alapjait, valamint az oktatási rendszer ezzel kapcsolatos általános és nagyon is kézzelfogható feladatait fogalmazza meg.

Jó olvasást, elmélkedést kívánunk, természetesen nemcsak a pedagógusok, hanem mindenki számára. Cupiditati nihilest satis, naturae satis est etiam parum $^{4}$, valamint: Vissza a természetbe!

\section{Irodalom}

Bagota, M., Csíkos, Cs. \& Szitányi, J. (2020). Introductory placement tests of students with primary school teacher major in Hungary. Gyermeknevelés Tudományos Folyóirat, 8(3), 24-34, https://doi.org/10.31074/gyntf.2020.3.24.34

Balogh B. \& B. Zsoffay K. (2020). Erdőóvoda. Gyermeknevelés Tudományos Folyóirat, 8(3), 221-236, https://doi.org/10.31074/gyntf.2020.3.237.252

Bauer Z. \& Gonda J. (2020). Tanuljunk emberséget az állatoktól! Gyermeknevelés Tudományos Folyóirat, 8(3), 93-115, https://doi.org/10.31074/ gyntf.2020.3.93.115

Csenger, L. (2015). A környezeti nevelés elmélete és gyakorlata. Képzés és Gyakorlat, 13(1-2.), 181-194.

Darvay S., Hill K., Fülöp V. \& Venyingi B. (2020). A környezeti fenntarthatóságra nevelés a bölcsődében. Gyermeknevelés Tudományos Folyóirat, 8(3), 131-144, https://doi.org/10.31074/gyntf.2020.3.131.144

Hamilton, C. (2015). Requiem for a Species. Earthscan.

Havas, P. \& Varga, A. (2006). A környezeti neveléstől a fenntarthatóság pedagógiai gyakorlata felé. In Varga, A. (Ed.), Tanulás a fenntarthatóságért (pp. 49-72). OKI.

Hill K. (2020). A természet közelségének jelentősége a 21. századi gyermekek fejlődésében. Gyermeknevelés Tudományos Folyóirat, 8(3), 217-220, https://doi. org/10.31074/ gyntf.2020.3.230.233

Klein Á. \& Márkus É. (2020). Képeskönyvek nyelvjárásban. Gyermeknevelés Tudományos Folyóirat, 8(3), 35-54, https://doi.org/10.31074/gyntf.2020.3.35.54

Kulman K. (2020). Tanító szakos hallgatók véleménye a magyarországi környezeti problémákról. Gyermeknevelés Tudományos Folyóirat, 8(3), 116-130, https:// doi.org/10.31074/gyntf.2020.3.116.130

Nagy B., Persa M. \& Munkácsy B. (2020). Helyzetkép az iskolai és iskolán kívüli környezeti szemléletformálásról. Gyermeknevelés Tudományos Folyóirat, 8(3), 145-165, https://doi.org/10.31074/gyntf.2020.3.145.165

Kaga, Y. (2008). Early childhood education for a sustainable word. In Samuelsson, I. P. \& Kaga, Y. (Eds.), The contribution of early childhood education to a sustainable society. 53-57. Gothenburg University. (2020.12.27.)

M. Nádasi, M. (2012). Adaptivitás az iskolában. ELTE Eötvös Kiadó.

${ }^{4}$ Semmi sem elég a vágynak, a természet kevéssel is beéri (Seneca). 
UNESCO (2010). Four Dimensions of Sustainable Development. www.unesco.org/ education/tlsf/mods/theme_a/popups/mod04t01s03.html. (2020.12. 29.)

Radnóti, K. (2005). Az önálló ismeretszerzésre alapozott tanítás lehetősége a természettudományi nevelésben. Új Pedagógiai Szemle, 55(10), 61-67.

Renz-Polster, H. \& Hüther, G. (2017). Vissza a gyökerekhez. Így fejlődnek „ezek a mai gyerekek". Ursus Libris.

Russell, W. (2020). Exploring the Dilemma of Planning for Play in Schools. Gyermeknevelés Tudományos Folyóirat, 8(3), 16-23, https://doi.org/10.31074/ gyntf.2020.3.16.23

Salonen, A., Tast, S. \& Hakari, S. (2013). Finnish Early Childhood Educators and Sustainable Development. Journal of Sustainable Development, 6(2), 70-85. https://doi.org/10.5539/jsd.v6n2p70 (2020. 12. 29.)

Tilbury, D., Coleman, V. \& Garlick, D. (2005). A National Review of Environmental Education and its Contribution to Sustainability in Australia-School Education. Australian Government Department of the Environment and Heritage and Australian Research Institute in Education for Sustainability (ARIES). http:// aries.mq.edu.au/projects/national_review/files/volume2/Volume2_Final05.pdf (2020. 12. 29.)

Timár G. (2020). Tudásszint és képességek változása a természettudományos képzés egy szegletében - Vélemény. Gyermeknevelés Tudományos Folyóirat, 8(3), 210216, https://doi.org/10.31074/gyntf.2020.3.1.210.216

Vincze Gy. (2020). Az erkölcsi ítéletalkotás fejlődése és fejlesztési lehetőségei intézményes keretek között. Gyermeknevelés Tudományos Folyóirat, 8(3), 72-92, https://doi.org/10.31074/gyntf.2020.3.72.92

WCED. World Commission on Environment \& Development. (1987). The Brundtland report: Our common future. Oxford University Press. https:// sustainabledevelopment.un.org/content/documents/5987our-common-future. pdf (2020. 12. 29.)

Wells, N. \& Lekies, K. S. (2006). Nature and Life Course: Pathways from Childhood Nature Experiences to Adult Environmentalism. Children, Youth and Environments, 16(1), 1-24. http://www.colorado.edu/journals/cye/ (2020. 12. 29.

Kolosai Nedda: https://orcid.org/0000-0001-7932-4443 